\title{
Unity in Diversity or Diversity in Unity: Indonesia's Process of Political Decentralisation and its Effects on Conflicts
}

\author{
By Hannah Neumeyer, London
}

\section{Introduction}

Indonesia is the biggest archipelagic state in the world, with roughly 17,000 islands, 6,000 of which are inhabited. The country has around 225 million inhabitants in many ethnic groups, speaking something between 250 and 600 different languages. ${ }^{1}$ Even though these factors suggest a decentralised system of government as the best option, Indonesia was a highly centralised country under the government of Soeharto. ${ }^{2}$ It was only after he resigned in May 1998, due to large scale and violent protests against him and the rapid economic downfall triggered by the Asian economic crisis, that a period of reform began. Soeharto handed over the presidency to his vice president Habibie. Despite this, protests continued since Habibie's presidency was based on the power of Soeharto. In order to build up some legitimacy and calm down the protests, Habibie promised free and fair elections for June 1999 and initialised a process of political decentralisation, ${ }^{3}$ i.e. the transfer of authority to subnational governments which are accountable to the populations of their territories. 4

Calls for an end of absolute supremacy of Jakarta over policy matters had already become louder towards the end of the Soeharto era. ${ }^{5}$ The resource rich regions of Indonesia increasingly felt that the profits from the exploitation of their natural resources were flowing into the central system without remuneration. Separatist movements, namely in Aceh, Papua (then Irian Jaya) and East Timor, became more fierce in their protests against the centre, and the Habibie government feared that national disintegration might be the consequence if

F. Lamoureux, Indonesia: A Global Studies Handbook, Santa Barbara, 2003, p. 7-8.

M. Buente, Regionale Autonomie in Indonesien - Wege zur erfolgreichen Dezentralisierung, Hamburg, 2003, p. 15.

3 E. Aspinall and G. Fealy, Introduction: Decentralisation, Democratisation and the Rise of the Local, in: E. Aspinall and G. Fealy (eds.), Local Power and Politics in Indonesia - Decentralisation and Democratisation, Singapore, 2003, p. 3.

4 M. Turner (ed.), Central-Local Relations in Asia-Pacific - Convergence or Divergence?, Hampshire, 1999, p. 6.

5

M. Turner and O. Podger, Decentralisation in Indonesia: redesigning the state, Canberra, 2003, p. 12. 
nothing was done to answer those protests. ${ }^{6}$ Apart from the separatist movements, a new form of inner-regional, communal conflict emerged in localities where positions in the provincial bureaucracy had been occupied by only one religious and/or ethnic group during the Soeharto era, excluding the other.

Substantial legislation regarding regional autonomy and fiscal relations between the centre and the regions was passed shortly before the first democratic elections were to be held in June 1999. Apart from the effects that are usually expected from political decentralisation, such as more efficiency in the delivery of public services and a more democratic form of governance, the main goal of this reform package was to inhibit national disintegration. It was hoped that the devolution of power from the centre to the regions would pacify the separatist movements. ${ }^{8}$ This is one of the positive effects that are generally attributed to devolution as throughout history, societies have attempted to reconcile diversities through devolution. The underlying premise is that people can govern themselves in peace once they are entrusted with their own destiny through democratic mechanisms. ${ }^{9}$

This paper will first present the Indonesian process of political decentralisation in general and highlight some of the problems. Secondly, it will set out the process and implementation of special autonomy for Papua as one example of the attempt to pacify independence movements through devolution of power. The better known independence movement in Aceh will not be included since the peace process that is under way there has been triggered more by international involvement after the tsunami catastrophe in December 2004 than by Indonesia itself. It is therefore not suitable to describe how the country itself tries to address separatist tendencies.

S. Asanuma and B. Brodjonegoro, Indonesia's Decentralization Policy: Origins, Issues and Policy Directions, 2003, http://www.gtzsfdm.or.id/documents/dec_ind/o_pa_doc/Shinji_Brodjonegoro_ Decentralization Policy_Sept2003.pdf, p. 2-3.

M. Malley, Indonesia: Violence and Reform Beyond Jakarta, in: Southeast Asian Affairs (2001), Singapore, p. 159-74, p. 167.

8 Ibid, p. 169.

9 J. Hatchard, M. Ndulo and P. Slinn, Comparative Constitutionalism and Good Governance in the Commonwealth, Cambridge, 2004, p. 184-185. 


\section{Drafting Process}

In order to honour his promises made, Habibie gathered a group of people and entrusted them with the task of drafting legislation to decentralise the country. ${ }^{10}$ This team of senior civil servants, academics and advisors ${ }^{11}$ had initially intended to encourage a wide debate about decentralisation. However, they quickly abandoned this intention both because of time constraints and a high level of acceptance of the draft within political circles. ${ }^{12}$

In May 1999, only one year after the resignation of Soeharto, the two main laws on the subject were passed through parliament without being contested or changed substantially. ${ }^{13}$ Law 22/1999 on Regional Autonomy redesigns the organisation of the state and the distribution of tasks by handing authority over to smaller entities at local level. Law 25/1999 on Centre-Regional Fiscal Balance in turn provides for the redistribution of fiscal resources in order to give the newly empowered entities the assets needed to perform their tasks. It is important to note in this context that the legislation was passed by a parliament that was the outcome of the last and undemocratic elections under Soeharto in 1997, and that was still controlled by Golkar, the ruling 'party' during the Soeharto era. ${ }^{14}$

The result of this short drafting process was a package of legislation that included one of the most radical projects of political decentralisation ever attempted anywhere in the world. ${ }^{15}$ This non-participatory and hurried process does certainly not adhere to requirements of good governance. However, the Habibie government might have had reasons for the way it acted.

P. Sulistiyanto and M. Erb, Introduction - Entangled politics in post-Suharto Indonesia, in: $M$. Erb, P. Sulistiyanto and C. Faucher (eds.), Regionalism in Post-Suharto Indonesia, New York, 2005, p. 6.

11 GTZ, Decentralization in Indonesia since 1999 - An Overview, http://www.gtzsfdm.or.id/dec_in_ ind.htm.

12

M. Turner and O. Podger, Decentralisation in Indonesia: redesigning the state, Canberra, 2003, p. 15.

13 M. R. Rasyid, Regional Autonomy and Local Politics in Indonesia, in: E. Aspinall and G. Fealy (eds.), Local Power and Politics in Indonesia - Decentralisation and Democratisation, Singapore, 2003, p. 63.

14 Golkar was not formally considered a party and acted more like an overarching organisation that controlled most public aspects of Indonesian life. See the description in D. Kingsbury, The Politics of Indonesia, Australia, 2002, p. 56-7. Affairs (2003), Singapore, p. 117. 


\section{$2.1 \quad$ General Instability}

From 1997 onwards, Indonesia was in a deep economic crisis. The currency lost almost 80 per cent of its value in only six months, causing massive unemployment and a dramatic increase in poverty. ${ }^{16}$ While this brought about the fall of Soeharto, and thus the chance for reform, it also led to a high degree of instability. Separatist movements were emerging and challenged national integrity. ${ }^{17}$ Concerns were voiced that unless something happened quickly, a so-called balkanisation of the archipelago would be the consequence. ${ }^{18}$ By demonstrating the will to reform the country, the Habibie government probably intended to improve its chances in the forthcoming elections. Nonetheless the intention of calming down the separatist movements through handing over power to the local level seems to have been genuine as well. ${ }^{19}$

\subsection{Political Uncertainty}

The general instability was coupled with a great degree of uncertainty about the composition of the next parliament after the first democratic elections that were to be held in June 1999. It was feared that the necessary cohesion for a strong legislative reform could not be found after the elections. ${ }^{20}$ In the wake of the fall of Soeharto, a flood of new political parties emerged, with as many as 48 meeting the requirements to participate in the elections in June $1999 .^{21}$ The most likely outcome of the elections, which proved to be right, was that no party would gain a significant majority in the new parliament. The next president, Wahid, belonged to a party that only held eight per cent of the seats in the body which then still elected the president. ${ }^{22}$ This government, instead of bringing the Indonesian reform process forward, was more engaged in ensuring its own survival. ${ }^{23}$

D. Bourchier and V. R. Hadiz (eds.), Indonesian Politics and Society - A Reader, London, 2003, p. 19.

17 S. Asanuma and B. Brodjonegoro, Indonesia's Decentralization Policy: Origins, Issues and Policy Directions, 2003, http://www.gtzsfdm.or.id/documents/dec_ind/o_pa_doc/Shinji_Brodjonegoro_ DecentralizationPolicy_Sept2003.pdf, p. 3.

18 M. Buente, Regionale Autonomie in Indonesien - Wege zur erfolgreichen Dezentralisierung, Hamburg, 2003, p. 11.

M. Malley, Indonesia: Violence and Reform Beyond Jakarta, in: Southeast Asian Affairs (2001), Singapore, p. 169.

20 M. Turner and O. Podger, Decentralisation in Indonesia: redesigning the state, Canberra, 2003, p. 20.

21 Ibid, p. 14.

22 A. Budiman, Indonesia: The Trials of President Wahid, in: Southeast Asian Affairs (2001), Singapore, p. 146.

23

M. Malley, Indonesia: Violence and Reform Beyond Jakarta, in: Southeast Asian Affairs (2001), Singapore, p. 171. 


\subsection{Impediment for Public Participation}

Public debate is understood to be crucial in the development of policies, especially in cases of substantial reform. The declared purpose of the decentralisation process in Indonesia was to allow for public participation in decisions that affect people locally and to thereby reduce the opposition against the central government. Yet the government did not motivate any public discussion about the reform. The assumption that the Habibie government was not committed to its promises does spring to mind.

Even though this might be the case, public debate would also have been difficult to conduct. At the time of drafting the legislation, civil society in Indonesia was still virtually non-existent. ${ }^{24}$ Organisations such as NGO's only emerged later and now do have the capacity to observe and evaluate government performance. The same is true for mass media, which during and shortly after the Soeharto era, rarely criticised the administration. ${ }^{25}$ In the regions, the only institutions that had any infrastructure and any stakes regarding the organisation of the state were Golkar, the ruling "party' ${ }^{26}$, and the military. Other political parties were only just emerging. ${ }^{27}$

\section{$2.4 \quad$ Ideological Explanations}

In addition to those rather practical explanations for a rushed and non-participatory drafting process, it is also important to note that the Indonesian state is to a significant extent based on ideology. Ever since independence, the country has emphasised the state ideology of Pancasila, comprising of five basic constitutional principles ${ }^{28}$ on which the nation is seen to be build. The principle of the unitary state has been interpreted after independence as meaning 'unity in diversity'. This accommodated both the reality of diversity within the Indonesian state and the wish for a strong nation. ${ }^{29}$ Even though the principles of the Pan-

M. Turner and O. Podger, Decentralisation in Indonesia: redesigning the state, Canberra, 2003, p. 19.

M. R. Rasyid, Regional Autonomy and Local Politics in Indonesia, in E. Aspinall and G. Fealy (eds.), p. 70.

See Fn. 12 above about the nature of Golkar.

27

M. Turner and O. Podger, Decentralisation in Indonesia: redesigning the state, Canberra, 2003, p. 19.

28 These principles are: (1) belief in one God; (2) humanitarianism; (3) the unitary state; (4) representation and consensus; (5) social justice. See M. Erb, P. Sulistiyanto, Introduction - Entangled politics in post-Suharto Indonesia, in M. Erb, P. Sulistiyanto and C. Faucher (eds.), p. 5.

S. Asanuma and B. Brodjonegoro, Indonesia's Decentralization Policy: Origins, Issues and Policy Directions, 2003, http://www.gtzsfdm.or.id/documents/dec_ind/o_pa_doc/Shinji_Brodjonegoro_ Decentralization Policy_Sept2003.pdf,p. 8. 
casila are vague and have always been interpreted according to the preferences of the respective government, they have nonetheless been internalised. ${ }^{30}$ The notion of the unitary state was of particular importance during the Indonesian independence movement and continued to be after independence. Any development towards federalism is still strongly opposed due to attempts of the Dutch to create a federal state of Indonesia. ${ }^{31}$ The concept of political decentralisation can easily be understood as being contrary to the principle of unity in diversity, and can even be seen as resembling federalism or moving towards it.

Furthermore, Indonesian politics are generally dominated by the Javanese. In the Javanese culture, the concept of power revolves around a ruler who represents the unity of society. Thus unity in itself is described as a symbol of power. ${ }^{32}$

These factors were probably not decisive for how the Habibie government conducted the drafting process. However, they are likely to represent underlying reasons for not initiating a broad public debate about the issue of political decentralisation.

\subsection{Conclusion}

In the period of drafting the legislation for the devolution of power, the Indonesian state was highly unstable. There was a general mistrust towards the dominant centralistic state which expressed itself not exclusively but most dangerously in separatist movements. This instability of the Indonesian society in general translated itself into politics and made it seem unlikely that a stable government and an effective parliament would emerge from the first democratic elections. Yet both are necessary to conduct a substantial reform process. At the same time, the general public called first and foremost for democratisation, but was not yet organised in a way conducive to the conduct of a broad public debate about the organisation of the state. Even though this is not to say that the so-called 'ordinary citizens' would have been unable to discuss the topic, an extensive period of time would certainly have been necessary in order to perform a productive public debate. All these factors, together with the strong value of unity in Indonesia in general, and on Java in particular, created an atmosphere that made it plausible that a rapid reform with rapid results was needed in order to prevent the country from drifting into chaos. In all this, the government certainly not only acted for the benefit of the country, but also in order to gain legitimacy and enhance its chances in the forthcoming elections. However, it seems that concerns

D. Kingsbury, The Politics of Indonesia, Australia, 2002 p. 35.

31 J. Alm, R. H. Aten and R. Bahl, Can Indonesia Decentralise Successfully? Plans, Problems and Prospects, in: Bulletin of Indonesian Economic Studies, Vol. 37, No. 1, (2001), p. 83.

32

N. Niessen, Municipal Government in Indonesia: Policy, Law, and Practice of Decentralisation and Urban Spatial Planning, Leiden, 1999, p. 337. 
about the country itself were at the forefront, not least because the legislation mandates a great loss of power at the central level.

The explanations given above do not remove the nimbus of 'bad governance' from the drafting process. However, the reform should not be condemned altogether without looking at the results that were achieved. If the reform delivers what it promised, i.e. the pacification of conflicts within Indonesia in the context of this paper, then the substance should not be discarded just because of the process.

\section{Law 22/1999 on Regional Autonomy}

Law 22/1999 on Regional Autonomy is the centre piece of the decentralisation laws that were passed under the Habibie government. This piece of legislation is usually referred to together with Law 25/1999 on Centre-Regional Fiscal Balance, which sets out the distribution of financial resources across Indonesia. Even though this is certainly as important as the devolution of power itself, I will only address the first piece of legislation in order to be able to focus on the interrelationship between devolution of power and conflict in Indonesia.

Law 22/1999 maintains the division of the country into provinces as the bigger units, and regencies and municipalities as the smaller units of sub-national government. However, the distribution of authority was changed substantially. While provinces were previously superior to regencies and municipalities, the two levels of local government now enjoy equal legal status. Furthermore, members of the executive are now elected at both levels as representatives of their region and are controlled by regional parliaments, whereas beforehand they were nominated by the central government and served as administrative agencies of the national government. 33

The legislation in principle transfers responsibility over all fields of government to regencies and municipalities, except for international policies, defence and security, judicature, monetary and fiscal policy, religion, and authorities in other fields. These 'other fields' are rather broadly worded policy areas such as national planning, human resource development or conservation and national standardisation. ${ }^{34}$ Apart from this negative list of policies not to be performed by regencies and municipalities, Law 22/1999 also includes a positive list

Pratikno, Exercising freedom - Local autonomy and democracy in Indonesia, 1999-2001, in $M$. Erb, P. Sulistiyanto and C. Faucher (eds.), Regionalism in Post-Suharto Indonesia, New York, 2005, p. 21. 
of matters that must be dealt with by them (e.g. health, education and culture, agriculture, etc.). ${ }^{35}$ The provincial level is now only responsible for cross-district matters, functions that regencies and municipalities are not yet ready to perform, and the administration of centralgovernment affairs in the regions. ${ }^{36}$

What stands out about the redistribution of tasks is that regencies and municipalities as the smaller entities rather than provinces gain power under the new system. While devolution of power does aim to bring the decision-making power closer to the people that are affected by the decisions, a balance has to be found between decentralising power and making governance ineffective through the creation of too many entities that decide autonomously. The principal reason for empowering regencies and municipalities in Indonesia seems to be that the central government did not want to create entities that would be big enough to seriously threaten Jakarta. The theory was that handing over most of the authority to entities that are too small to become very powerful, separatist movements would not be able to gather the necessary strength to break away from the state. ${ }^{37}$ Furthermore, the government intended to avoid the appearance of moving towards a federalist system. ${ }^{38}$ Law 22/1999 was seen as a workable compromise between the broadly supported understanding that the centralised system was no longer tenable, and the opposition to federalist tendencies. 39

Regarding the character of regional autonomy Law 22/1999 states that it is based on the principles of democracy, community participation, equitable distribution and justice. It suggests that announces as a necessity the organisation of regional autonomy by granting broad, real and accountable regional governments in accordance with regional potentials and diversity is a necessity. ${ }^{40}$ Even though the system is not a federal one, where autonomy would be constitutionally guaranteed, the Constitution states that the autonomy granted

See Law 22/1999, Article 11 (2).

H. Crouch, Indonesia: Democratisation and the Threat of Disintegration, in: Southeast Asian Affairs (2000), Singapore, p. 126. See also Law 22/1999, Article 9.

S. Asanuma and B. Brodjonegoro, Indonesia's Decentralization Policy: Origins, Issues and Policy Directions, 2003, http://www.gtzsfdm.or.id/documents/dec_ind/o_pa_doc/Shinji_Brodjonegoro_ DecentralizationPolicy_Sept2003.pdf,p. 4.

N. Devas, Indonesia: What do we mean by decentralisation?, in: Public Administration and Development, Chichester, Vol. 17 No. 3, (1997), p. 352. (eds.), Local Power and Politics in Indonesia - Decentralisation and Democratisation, Singapore, 2003, p. 63.

40

Law 22/1999 clause a, b and c of the Preamble. 
shall be wide-ranging ${ }^{41}$, thus constitutionally protecting regional autonomy to a certain extent.

At first sight, Law 22/1999 seems to be a major positive step. By handing over responsibilities to the local level, it empowers regencies and municipalities to freely choose the direction of their policies. Separatist movements strive for independence and not only for a wide degree of autonomy. However, the devolution of power can have the potential of drying out support for those movements if it can convince people that separation from the state has become unnecessary in order to be able to direct politics according to their will. However, there are some problems within the Indonesian legislative framework.

While the legislation provides a general framework for reform, it leaves the drafting of detailed regulations in the hands of the national government. Thus the interpretation of the law is left with national bureaucrats whose power it intends to minimise. Furthermore, Law $22 / 1999$ is not clearly worded, leading to a wide scope of possible interpretations. This can be seen in Article 7 with its broad list of 'other authorities' reserved for the central government. Unless the central government is committed to decentralisation, this provision has the potential of undermining the purpose of the legislation if regulations are passed that bring back authority to the central level. Also, the division of labour between provinces on the one hand and regencies and municipalities on the other is ambiguous. By stating that provinces remain responsible for tasks that regencies and municipalities are not yet ready to perform $^{42}$, the legislation virtually seems to intend to create conflicts over competence.

\section{Implementation}

The implementation of the legislation for decentralisation was as rushed as its drafting process. While implementation was first envisaged for May 2001, two years after its promulgation, this period was shortened to January 2001 in August 2000, leaving the government of Wahid an even shorter period of time to make the necessary preparations. ${ }^{43}$ This is said to have been beyond the capacity of the government, not only but also due to a cabinet reshuffle in which Rasyid, the head of the drafting team and responsible for the

See Article 18 (5) of the Constitution, in: A. P. Blaustein and G. H. Flanz (eds.), Constitutions of the countries of the world: a series of updated texts, constitutional chronologies and annotated bibliographies, New York, 1971-2003.

42

See Article 9 of Law 22/1999.

43

M. Turner and O. Podger, Decentralisation in Indonesia: redesigning the state, Canberra, $2003 \mathrm{p}$. 18. 
implementing regulations, was replaced by a conservative army general. ${ }^{44}$ Even more than the rushed drafting process and the consequential ambiguity, a flawed implementation process has the potential of undermining the aim of legislative reform.

On the practical level, the transfer of powers in sectors such as education and health went smoothly. The central government personnel was transferred from the former offices of the central government in the regions to the authority of regencies and municipalities. Services generally continued to function throughout the process. 45

However, problems are reported regarding the development and budgeting of local policies. Whereas under the old system, the local level simply executed the policies as required by central guidelines, the decisions are now made by the local legislature and executive along objectives that they themselves develop. This at times led to inappropriate policies such as "nuisance taxes", unwise projects and expenditure decisions, etc. ${ }^{46}$ Local government regulations also frequently breach the decentralisation laws due to their ambiguity and the lack of supervision. ${ }^{47}$

Furthermore, the regulations issued within the first two years of implementation of Law $22 / 1999$ are said to confuse the division of power further. Some regulations even suggest that central ministries have tried to prevent the transfer of their powers to the regions. In addition to that, old legislation has not been changed to accommodate the new situation, thus leading to overlapping authorities where regencies and municipalities have been assigned tasks that at the same time were not withdrawn from the authority of central government agencies. $^{48}$

All this seems to suggest that the process of decentralisation does not receive the necessary attention in order to accomplish such an extensive reform. Whether this is because the governments following Habibie disagree with the reform as such, or lack the capacity to implement it, is difficult to determine. But it certainly does not assist in the process of

M. Malley, Indonesia: Violence and Reform Beyond Jakarta, in: Southeast Asian Affairs (2001), Singapore, p. 171.

G. F. Bell, Indonesia: The New Regional Autonomy Laws, Two Years Later, in: Southeast Asian Affairs (2003), Singapore, p. 122.

S. Asanuma and B. Bodjonegoro, Indonesia's Decentralization Policy: Origins, Issues and Policy Directions, 2003, http://www.gtzsfdm.or.id/documents/dec_ind/o_pa_doc/Shinji_Brodjonegoro_ DecentralizationPoli cy_Sept2003.pdf,p. 16. (eds.), Local Power and Politics in Indonesia - Decentralisation and Democratisation, Singapore, 2003, p. 70.

G. F. Bell, Indonesia: The New Regional Autonomy Laws, Two Years Later, in: Southeast Asian Affairs (2003), Singapore, p. 121. 
transition to a democratic state with peaceful relations between the centre and the regions. Instead of calming down separatist movements, the process of decentralisation has even led to the emergence of regional riots along ethnic or religious lines where demands for a leadership that is native to the region excluded other ethnicities or religious groups from participation, such as in the Moluccas. ${ }^{49}$

\section{Papuan Special Autonomy}

Indonesia embarked on a problematic reform process from a highly centralised to a highly decentralised form of government and, by doing so, created a new form of conflict. I will now turn to the example of Papuan special autonomy to determine whether at least the objective of pacifying separatist movements has been achieved. According to Rasyid, the relationship between Papua and Jakarta was negotiated in a spirit of regional autonomy and provides a basis for lasting stability. ${ }^{50}$

The Papuan independence movement arose when the territory became part of Indonesia in 1962. Until then, it had remained under Dutch control in order to be prepared for independence. However, Cold War considerations and Indonesian claims to the territory led to the abandonment of this plan and 1,025 handpicked Papuan delegates agreed to be transferred to Indonesia. ${ }^{51}$ The Indonesian military reacted harshly against the small scale armed resistance, and not only against insurgents, but also against civilians, creating bitter resentment against the state. ${ }^{52}$

After the resignation of Soeharto, Papuan leaders demanded a dialogue to address the provinces concerns. Soon, calls for independence emerged and the independence movement developed from a symbolic armed struggle to a movement with strong popular backing. ${ }^{53}$ The military again reacted strongly, claiming to defend the integrity of the state,

J. S. Davidson, Decentralization and Regional Violence in Post-Suharto State, in M. Erb, P. Sulistiyanto and C. Faucher (eds.), Regionalism in Post-Suharto Indonesia, New York, 2005, p. 172.

M. R. Rasyid, Regional Autonomy and Local Politics in Indonesia, in E. Aspinall and G. Fealy (eds.), Local Power and Politics in Indonesia - Decentralisation and Democratisation, Singapore, 2003, p. 71.

R. McGibbon, Between Rights and Repression: The Politics of Special Autonomy in Papua, in E. Aspinall and G. Fealy (eds.), Local Power and Politics in Indonesia - Decentralisation and Democratisation, Singapore, 2003, p. 195.

D. Kingsbury and H. Aveling, Introduction, in D. Kingsbury and H. Aveling (eds.), Autonomy and 
which led to violent conflicts with local communities by $2000 .{ }^{54}$ The conflict eventually persuaded Habibie to discuss the political status of the region. ${ }^{55}$

As a reaction to the discussion of Papuan special autonomy at the central level, Papuan leaders began to work on a counter-draft and encouraged public discussion and contributions from all parts of society in the process. ${ }^{56}$ After initial rejection by Jakarta, the Papuan draft eventually received support from important members of the national parliament and the executive, thus pushing forward the process and leading to quick adoption by parliament in November 2001. Although some changes were made, the law still contained major concessions to Papuan demands. ${ }^{57}$ However, the law does not enjoy popular support due to deep mistrust towards the central government. It is only accepted by local officials and academics who see it as a middle way that has the potential to end the conflict between Papua and Jakarta. ${ }^{58}$

The law does in fact grant significant autonomy. It transfers most powers to the province instead of regencies and municipalities, as provided for by the general legislation. Furthermore, it recognises customary law, mandates affirmative action to include Papuans in public positions, provides protection and recognition of basic rights of local Papuan communities, puts a stop to the exploitation of resources by the central government and creates a Papuan People's Assembly with wide-ranging powers over regulations and candidates for governorship.

In theory, this law does seem to transfer sufficient authority to pacify claims for independence. If it was thoroughly implemented and Papuans could experience that the autonomy granted is put into practice, the independence movement would probably loose momentum.

M. Malley, Indonesia: Violence and Reform Beyond Jakarta, in: Southeast Asian Affairs (2001), Singapore, p. 164.

S. Zoellner, Autonomy for Papua - Opportunity or Illusion: Introduction, Berlin, 2003, http://home.snafu.de/watchin/AfP2003intro.htm.

57 R. McGibbon, Between Rights and Repression: The Politics of Special Autonomy in Papua, in $E$. Aspinall and G. Fealy (eds.), Local Power and Politics in Indonesia - Decentralisation and Democratisation, Singapore, 2003, p. 198.

S. P. Morin, Autonomy for Papua - Opportunity or Illusion: Popular Participation since the Special Autonomy Law for the Province of Papua came into effect, Berlin, 2003, http://home. snafu.de/watchin/AfP2003morin.htm. 
However, as with the general decentralisation process, the implementation process has not been running smoothly. Shortly after the law was passed through parliament, the Papuan independence leader, Theys Eluay, was murdered by the military, giving rise to speculations that the military wanted to prevent autonomy and highlighting that it operated with impunity in Papua. ${ }^{60}$ Understandably, this revived calls for independence and reinforced the impression among Papuans that the central government was not seriously committed to its promises. Furthermore, there have been reports in 2002 that a civilian militia with relations to the military was being formed, leading to concerns that something similar to the attacks on civilians in East Timor after the referendum might happen in Papua. ${ }^{61}$

Apart from those alarming reports, the implementation process has become even more problematic under the Megawati administration, which took office in July 2001. There is clearly no commitment to the decentralisation policy and the government was accused by the media to act half heartedly regarding decentralisation. ${ }^{62}$ Implementing regulations passed by the Papuan government that had to be approved by Jakarta were put on hold. This logjam policy has also been applied to the formation of the Papuan People's Assembly, which probably constitutes the most important element of the Papuan autonomy legislation. Furthermore, a presidential instruction was passed in 2003 that partitions Papua into three provinces and, in doing so, contradicts the very wording of the special autonomy law. ${ }^{63}$ This also seems to suggest that Jakarta tries to break the strength of the Papuan province, as the division into smaller entities is in line with the objective described above to not vest provinces with too much power.

Even more than at the general level of decentralisation policy, the case of Papua suggests that the Indonesian government is applying a policy of one step forward, two steps backward and is not committed to the declared aim of establishing peaceful relations between the central and the local level.

International Crisis Group, Indonesia: Resources and Conflict in Papua, ICG Asia Report $\mathrm{N}^{\circ} 39$, Jakarta/Brussels, 2002, http://www.crisisgroup.org/library/documents/report_archive/A400774_ 13092002.pdf.

R. McGibbon, Between Rights and Repression: The Politics of Special Autonomy in Papua, in $E$. Aspinall and G. Fealy (eds.), Local Power and Politics in Indonesia - Decentralisation and Democratisation, Singapore, 2003, p. 204-6.

S. Zoellner, Autonomy for Papua - Opportunity or Illusion: Introduction, Berlin, 2003, http:// home.snafu.de/watchin/AfP2003intro.htm.

Ibid. 


\section{Conclusion}

Indonesia began a rapid process of democratisation after the resignation of Soeharto. An important element of this attempt was the decentralisation of power from the central to the local level, which was devised to both democratise the country and to counteract the possibility of national disintegration through independence movements. While Jakarta at the outset of the reform process did show itself prepared to negotiate special autonomy with the province of Papua in order to silence the independence movement, its commitment to the process soon vanished. This probably even strengthened the claims for independence by counteracting the promises that had been made.

Apart from failing in the attempt to pacify separatist movements, the devolution of power also led to the emergence of conflicts within regions. The decentralised authority has in many regions been monopolised by one ethnic or religious group, leading to violent conflicts between the groups. As is the case with the special autonomy for Papua, this result also seems to be due to the flawed process of implementation that created even more confusion than the basic legislation had already done.

Overall, the process of devolution of power can be said to have created more problems than it solved. The principal reason for this is probably that the government decided to rush the reform instead of first devising the objectives and then the policies to achieve them. The unstable conditions after the resignation of Soeharto and the prospect that a public debate about the reform would have led to a lengthy process with an uncertain outcome make this rush comprehensible. However, this decision was especially precarious in Indonesia, where the concept of the unitary state was internalised not only by the political elite, but also by society in general. In the end, the Indonesian example shows that a poorly prepared and poorly executed reform can generate additional problems, while not solving the ones it meant to address. 